Res Publica. Revista de Historia de las Ideas Políticas ISSN-e: 1989-6115

\title{
El comercio como signo de civilidad en la prensa colonial de Buenos Aires (1801-1810)*
}

\author{
Matías Maggio-Ramírez ${ }^{* *}$
}

Recibido: 11/08/2018 / Aceptado: 14/12/2018

Resumen. El comercio y la civilidad se encontraron anudados en la prensa colonial porteña como una estrategia identitaria para demostrar que en Buenos Aires se encontraba a la par de las ciudades euro-peas y que también reinaban las ideas ilustración francesa mediadas por los intelectuales católicos es-pañoles. El comercio era un signo de civilidad, ya que implicaba el diálogo entre las partes, así como el pago de impuestos reales a diferencia del contrabando. La prensa porteña cuestionó el contrabando como una práctica ligada a la barbarie urbana que había que desterrar así como fomentó la civilidad y el comercio como la forma de habitar la ciudad en favor de la felicidad del pueblo.

Palabras clave: civilidad; comercio; prensa colonial; Buenos Aires; Telégrafo Mercantil; Semanario de Agricultura; Industria y Comercio.

\section{[en] Trade as a Sign of Civility in the colonial Press of Buenos Aires (1801- 1810)}

\begin{abstract}
Trade and civility were found to be knotted in the Buenos Aires colonial press as an identi-ty strategy to show that Buenos Aires was on par with European cities and that the ideas of French enlightenment mediated by Spanish Catholic intellectuals also reigned. Trade was a sign of civility, as it involved dialogue between the parties, as well as the payment of real taxes as opposed to smuggling. The Buenos Aires press questioned contraband as a practice linked to the urban barbarism that had to be banished as well as promoting civility and commerce as the way to inhabit the city in favor of the happiness of the people.
\end{abstract}

Keywords: Civility; Trade; Colonial Press; Buenos Aires, Telégrafo Mercantil; Semanario de Agri-cultura; Industria y Comercio.

Sumario. 1. Presentación. 2. La civilidad en la prensa. 3. Reformas borbónicas y comercio porteño. 4. Corte, comercio y civilidad. 5. Civilidad y caminos. 6. El contrabando en la prensa. 7. Cierre.

Cómo citar: Maggio-Ramírez, M. (2019). El comercio como signo de civilidad en la prensa colonial de Buenos Aires (1801-1810), en Res Publica 22.1, 87-104.

\footnotetext{
* Este artículo tiene como punto de partida la tesis doctoral "Civilidad imaginada. La construcción de la civilidad como signo identitario en la prensa tardocolonial porteña. Un análisis del Telégrafo Mercantil, Rural, Político, Económico e Historiográfico del Río de la Plata y del Semanario de Agricultura, Industria y Comercio entre 1801-1803" defendida en la Facultad de Ciencias Sociales de la Universidad de Buenos Aires en agosto del 2016.

** Universidad Nacional de Tres de Febrero, Argentina mmramirez@untref.edu.ar
} 


\section{Presentación}

"El comercio cura las preocupaciones destructivas" fue la cita que Juan Hipólito Vieytes, editor del Semanario de Agricultura, Industria y Comercio, tomó de Montesquieu para argumentar en favor de la economía mercantil pero también por su influencia en el ámbito social. La cita recalcaba que "es casi regla común que donde hay costumbres suaves, haya comercio, y que donde hay comercio haya costumbres suaves"1. En Buenos Aires, una ciudad mercantil en crecimiento a principios del siglo XIX en los confines del imperio borbónico, se cifró en el comercio la clave para el fomento de las buenas maneras. Se propone aquí rastrear en la prensa tardocolonial porteña cómo el comercio fue interpretado como signo de civilidad por parte de la élite criolla local.

La cita de la obra de Montesquieu utilizada por Vieytes condensaba el epíritu dieciochesco de la economía política y el republicanismo y que ya había tenido una formulación similar en las Cartas de Catón, que John Trenchard y Thomas Gordon publicaron a principios del XVIII en el periódico London Journal y luego en el British Journal, cuando se sostuvo que "la virtud y la libertad protegen el comercio y, a su vez, el comercio asegura la libertad y la civilización: el refinamiento de las costumbres"2. El comercio como signo de la pacificación de las pasiones entre naciones se encontró en los Discursos sobre el fomento de la industria... del conde Pedro Rodríguez de Campomanes, que tradujo el Espíritu de las leyes bajo el título Alma de las leyes sin que fuera dado a la imprenta ${ }^{3}$, cuando sostuvo que las "Repúblicas mantienen su independencia por virtud del comercio. Éste no se aumenta con la posesión de muchas Provincias ni de una larga extensión de País que se halle despoblado y falto de agricultura e industria"4. La obra de Montesquieu circuló con fervor entre las bibliotecas del Río de la Plata ${ }^{5}$, al igual que los escritos de Campomanes que fueron invocados como guía en el "Análisis" del primer periódico impreso porteño entre 1801 y 1802, el Telégrafo Mercantil, Rural, Político, Económico e Historiográfico del Río de la Plata. En la Europa dieciochesca, así como en los confines coloniales, escribir sobre economía era hacerlo sobre política y gobierno. Más aún en el ámbito hispánico donde bajo la égida virreinal no había un debate político abiertamente. Durante el reinado de Carlos III y hasta 1812 se publicaron casi un centenar de obras sobre economía política de distintas doctrinas y géneros discursivos desde periódicos, diccionarios o enciclopedias 6 .

“Comercio”, Semanario de Agricultura, Industria y Comercio, Tomo 1, N 3, 6/10/1802, pp. 17-24, aquí p. 17 [Disponible en https://babel.hathitrust.org]

2 J. G. A. Pocock, "El debate del siglo XVIII. Virtud, pasión y comercio", en El Momento maquiavélico: el pensa-miento político florentino y la tradición republicana atlántica. Madrid: Tecnos, 2002, pp. 559-605, aquí p. 568.

3 B. Clavero Salvador, "Del Espíritu de las leyes: Primera traducción truncada.", Anuario de Historia Del Derecho Español, 55 (1985), pp. 767-772.

4 P. Rodríguez Campomanes, Discurso sobre el fomento de la industria popular. Biblioteca Virtual Miguel de Cer-vantes, http://www.cervantesvirtual.com/nd/ark:/59851/bmcj9652 . Accedido 2 de marzo de 2019.

5 A pesar de la prohibición la obra de Monstesquieu circuló entre la ilustración criolla en ambas márgenes del Río de la Plata ya que se encontró mención de sus obras en los inventarios del obispo de Buenos Aires Manuel Azamor y Ramírez así como de los eruditos Juan Baltazar Maziel, Antonio José de Escalada, Juan Hipólito Vieytes, Facundo de Prieto y Pulido, Ignacio Flores y Figueredo y Francisco de Ortega; según el relevamiento de J. Peire, "Leer la Revolución de Mayo: Bibliotecas tardocoloniales en el Río de la Plata", Eadem Utraque Europa, VI, 2008, pp. 109-155, aquí p. 148.

6 J. Usoz, "Los prólogos económicos y la esfera pública ilustrada en España” en J. Astigarraga y J. Usoz (eds.), 
El título del periódico de Vieytes no sólo demarcaba el campo temático a tratar dentro del cam-po semántico de la economía política sino hizo hincapié en la secuencia, de acuerdo con los parámetros de la ilustración escocesa, para que los frutos de la tierra terminaran en el comercio pero para llegar a esa instancia había que cambiar las costumbres ${ }^{7}$. En las primeras páginas del Semanario sostuvo que "[1]a experiencia de todos los siglos nos demuestra que el grado de civilización, cultura y opulencia a que puede llegar una nación es solamente debida a la más o menos acogida y libertar que hay dado a su comercio"8. Los teóricos de la economía política había corrido el eje del poder centrado en la "fuer-za y la conquista por los de la economía y el «dulce comercio», [por lo que se otorgaría] un gran pro-tagonismo al desarrollo de los sectores productivos y del comercio [...]"9.

Para apuntalar las ramas productivas y su ingreso en el comercio se apelaba en la prensa a la modificación de las tradiciones y conocimientos transmitidos generacionalmente por los saberes escriturarios. Entre las escenas ficcionales de lectura que se representaron en la prensa tardocolonial porte-ña se reiteraba aquella en que el ciudadano patriota y el párroco ilustrado transmitirían a la plebe y al campesinados los saberes que de los libros habían sido adaptados en la prensa para su divulgación ${ }^{10}$. Por ejemplo cuando Vieytes utilizó como fuente el Diccionario Universal de Agricultura del abate Rozier para su catecismo agrario que publicó en su periódico.

J. G. A. Pocock sostuvo que Adam Smith creía que el hombre debía practicar el comercio antes de ser un sujeto capaz de ser ciudadano ${ }^{11}$. El comercio era entonces el punto último que permitiría fortalecer el ideal civilizatorio que se difundió desde la prensa ya que implicaba un espacio de interrelación en donde primaba el diálogo, en una ficción enunciativa entre pares, frente al arrebato ${ }^{12}$. El contrabando y la piratería eran cuestionados principalmente porque atentaban contra la autoridad real. En la prensa se hizo especial hincapié en el fomento del comercio porque así se eviden-

L'économie politique et la sphére publique dans le débat des Lumieéres, Casa de Velázquez, 2013, pp. 83-101, aquí pp. 83-84.

7 Sobre la relación difusión de las ideas económicas en la prensa virreinal se destacan los trabajos de N. Calvo y R. Pastore, "Ilustración y economía en el primer periódico impreso del Virreinato del Río de la Plata: el "Telégrafo Mercantil" (1801-1802)", Bulletin hispanique, Tomo 107, n 2, 2005, pp. 433-462, M.V. Fernández Armesto, "Lectores y lecturas económicas en Buenos Aires a fines de la época colonial”, Información, Cultura y Sociedad, $\mathrm{n}^{\circ}$ 13, 2005, pp. 29-56 y P. Martínez Gramuglia, "El pensamiento agrario ilustrado en el Río de la Plata: un estudio del Semanario de Agricultura, Industria y Comercio (1802-1807)", Mundo agrario, Vol. 9, ${ }^{\circ}$ $18,2009$.

8 Semanario de Agricultura, Industria y Comercio, Buenos Aires, Junta de Historia y Numismática Americana, 1928-1937, Tomo 1, pp. 25-27.

9 J. Usoz, op. cit. p. 83.

10 M. Maggio Ramírez, "El Telégrafo Mercantil y el fomento de la civilidad. El nacimiento de la prensa de costum-bres en el Buenos Aires virreinal”, Historia y Comunicación Social, Vol. 22, n 1, 2017, pp. 31-44.

11 J. G. A. Pocock, op. cit., p. 603.

12 En zonas de contacto entre el español penisular y el criollo con los pueblos originarios la capacidad de intercambio y el pago de tributos los acercaba tangencialmente a la civilización a diferencia de quienes se negaban y eran parte de malones. Nicolás Kwiatkowski, "Representaciones de la barbarie europea y americana durante los siglos XVI y XVII”, Prismas, n. ${ }^{\circ} 18,2014$, pp. 29-62, analizó los orígenes clásicos de las representaciones de la barbarie europea y americana durante la Ilustración. Destacó que tanto los criollos como los españoles utilizaron de manera indistinta los términos "bárbaros", "salvajes", "bravos", "feroces", "infieles", "gentiles" o “indómitos” pero remarcó por ejem-plo que Francisco de Paula Sanz, en 1780, de paso por el Virreinato del Río de la Plata, consideró que "los indios que pagaban tributo estaban «entre los más civilizados» pese a lo cual eran incapaces de «escapar a la barbarie» pues mantenían «sus antiguas costumbres, trajes e idiomas»" 
ciaban las costumbres suaves de una ciudad que buscaba su recocimiento frente la mirada de las metrópolis europeas. Es decir, el fomento del comercio en la prensa tardocolonial apostaba al reconocimiento de Buenos Aires como una ciudad acorde a los tiempos modernos. La élite criolla y letrada, en menor intensidad y sin una prosa contundente como la de los jesuitas exiliados, buscó así contrarrestar a los filósofos europeos como Cornelius de Paw, el conde de Buffon y Montesquieu, entre otros, que imaginario el territorio americano signado por la barbarie ${ }^{13}$.

\section{La civilidad en la prensa}

En 1801 los lectores porteños recibieron con entusiasmo la novedad de un periódico impreso en la sede del reciente virreinato del Río de la Plata. En sus páginas, tanto el editor del Telégrafo Mer-cantil, Rural, político, económico e historiógrafo del Río de la Plata (1801-1802), como el del Semanario de Agricultura, Industria y Comercio (1802-1807) ${ }^{14}$ interpelaron a sus lectores para que inter-vinieran en los periódicos, divulgaran sus contenidos y modificaran sus costumbres. En los periódicos no sólo se encontraron las plumas de dramaturgos y literatos como Manuel José de Lavardén y Domingo de Azcuénaga sino también Manuel Belgrano, Pedro Antonio Cerviño, el deán Gregorio Funes, Gabriel Antonio Hevia y Pando, entre otros eruditos que encontraron en el espacio de la prensa el lugar donde volcar sus inquietudes en favor del progreso y el bien común, aunque se escondieran entre iniciales, seudónimos y anagramas.

Uno de los temas que preocupó a la comunidad letrada relacionada a la prensa local fue el fomento de la civilidad, en tanto código de comportamiento para habitar la ciudad. Los lectores de los periódicos cifraron en la civilidad un signo de la identidad tanto americana como porteña ${ }^{15}$. Esto operó como una marca diferencial al interior del mundo urbano para diferenciar a la élite de las múltiples castas, artesanado y campesinado. Por ejemplo, en una de las escenas ficcionales de lectura, que se representaron en la prensa, se incorporó al campesino como receptor pasivo de las enseñanzas que el lector urbano del periódico, rodeado de libros y conocimientos de la "sabia Europa", le transmitiría en sus visitas rurales. Las "buenas maneras" también necesitaban inculcarse en la ciudad, tanto cuando a causa de sus gustos por el lujo y la moda las mujeres llevaban a su marido a la ruina o porque el comerciante atentaba contra el rey al comprar mercaderías de contrabando ${ }^{16}$. Por otro lado, al destacarse en la prensa las "buenas maneras" de los españoles americanos, se cuestionaba el enfoque que la literatura y prensa europeas tenían sobre las costumbres en las ciudades del Nuevo Mundo.

Al cuadruplicarse la población de Buenos Aires, tras la habilitación comercial

13 A. Gerbi, La disputa del Nuevo Mundo. Historia de una polémica 1750-1900, México, Fondo de Cultura Económica, 1960.

14 Telégrafo Mercantil: rural, político-económico e historiógrafo del Río de la Plata, Buenos Aires, Junta de Histo-ria y Numismática Americana, 1914-1915, 5 tomos. Semanario de Agricultura, Industria y Comercio, Buenos Aires, Junta de Historia y Numismática Americana, 1928-1937, 5 tomos. También se encuentran disponibles para su consulta en https://babel.hathitrust.org

15 M. Maggio Ramírez, "El color de la palabra. Sobre la sátira de Manuel José de Lavardén y su polémica en el Telé-grafo Mercantil (1786-1801)", Dieciocho: Hispanic enlightenment, $\mathrm{N}^{\circ} 38$, vol. 2, 2015, pp. 219-238.

16 M. Maggio-Ramírez, "El lujo y la moda como signos identitarios en la prensa del Buenos Aires virreinal (18011807)”. Cuadernos de Ilustración y Romanticismo, vol. 24, n. ${ }^{\circ}$ 1, 2018, pp. 637-654. 
de su puerto luego de la conformación del virreinato del Río de la Plata, el problema sobre cómo habitar la ciudad fue una preocupación tanto en las regulaciones urbanas como en los periódicos que apelaban a la sociabilidad a los comerciantes, principales suscriptores, seguidos por burócratas, militares y clérigos ${ }^{17}$. La civilidad, en tanto buenas maneras, ligada a la sociabilidad se encontraba en la Enciclopedia en el artículo redactado por Jaucourt en el que asociaba al hombre sociable con el trato humano que buscaba el bien común en oposición al hombre amable que poco le importa la felicidad pública y que no quiere a nadie. Allí se cifraba una "cortesía presuntamente artificial e incluso antisocial y otra constitutiva de la res publica"18 que implicaba el diálogo, el comercio y la diferenciación estamental y étnica en los espacios públicos que se encontraron históricamente reglados en su puesta en escena por la legislación suntuaria.

Los lectores fueron interpelados por la prensa para que sean cómplices de la empresa gráfica con el pago de la suscripción y el envío de colaboraciones. Estas servirían para que otros lectores conozcan la sociedad, economía e historia del amplio territorio virreinal como estrategia para reforzar la identidad local, que tuvo múltiples adscripciones, y fomentar el progreso económico. Tanto en el Telégrafo Mercantil como en el Semanario de Agricultura, las colaboraciones de los lectores americanos, que no sólo buscaban que su nombre estuviera en letras de molde, tuvieron la misma importancia que la reproducción de los escritos publicados en los periódicos extranjeros, algunos traducidos del francés o el inglés en la prensa española como en El espiritu de los mejores diarios de Cristobal Cladera. La prensa tardocolonial imaginó a sus lectores en el papel de mediadores de la palabra, lectores colectivos para públicos ajenos a la cultura impresa. Además de los textos programáticos de los "hombres ilustres", como el conde de Campomanes, se incluyeron cuestiones como las costumbres y maneras urbanas de comportarse en sociedad.

El trabajo pionero de Norbert Elias destacó que desde el siglo XVI la aristocracia cortesana europea fue una nueva clase dominante en una sociedad pacificada ${ }^{19}$. Los cortesanos en su interrelación con la burguesía difundieron los "buenos modales" que habían aprendido en la literatura instruc-cional de matriz erasmiana, centrada en el control de los afectos y la disciplina en las acciones ${ }^{20}$. La transformación del aparato psíquico en el proceso civilizatorio operó desde la infancia, cuando se les inculcó la "regulación cada vez más diferenciada y estable del comportamiento, como si fuera algo automático, como si fuera una autocoacción de la que no pueden liberarse aunque lo quieran conscientemente" 21 . Este proceso fue resignificado y propagado por la iglesia, principalmente desde las instituciones educativas, que en algunos casos elaboraron manuales de educación moral y cristiana. Tras el ascenso social de

17 P. Martínez Gramuglia, “A la búsqueda de lectores: El Telégrafo Mercantil”. Question, vol. 1, n. ${ }^{\circ} 27,2010$. perio.unlp.edu.ar, http://perio.unlp.edu.ar/ojs/index.php/question/article/view/1000. Un estudio pionero sobre los suscriptores del Telégrafo puede hallarse en M. Martini, Francisco Antonio Cabello y Mesa: un publicista ilustrado de dos mundos (1786-1824), Buenos Aires, Instituto de Investigaciones sobre Identidad Cultural, Universidad del Salvador, 1998.

18 P. González Bernaldo de Quiroz, Civilidad y politica en los orígenes de la Nación Argentina. Las sociabilidades en Buenos Aires, 1829-1862. Fondo de Cultura Económica, 2000, p. 87.

19 N. Elias, El proceso de la civilización. Investigaciones sociogenéticas y psicogenéticas, México, Fondo de Cultura Económica, 1994.

20 J. Varela, "Comentario", en Erasmo, De la urbanidad en las maneras de los niños = [De civilitate morum puerilium], Madrid, Servicio de Publicaciones del Ministerio de Educación y Ciencia, 2006, pp. 79-112, aquí p. 84.

$21 \quad$ N. Elias, op.cit., p. 452. 
la burguesía en el siglo XVIII, la nobleza cortesana perdió fuerza, al igual que el término civilidad. En su reemplazo, emergió en Europa el uso de la palabra civilización como "una red de restricciones que tienen a la atenuación de los excesos y a un control cada vez más individualizado"22. En el Siglo de las Luces, los manuales de urbanidad comenzaron a incorporar consejos relacio-nados a la higiene corporal y la salud, así como hicieron especial hincapié en la familia como el principal transmisor de las reglas de buena crianza. El proceso de control y represión de las pasiones de la sociedad cortesana en función de una sociedad estamental mutó en criterios menos evidentes por su carencia de teatralidad barroca pero eficaces para lograr el autocontrol y disciplina en la interacción social ${ }^{23}$. En España, los conceptos de civilidad y civilización no se impusieron, pero sí lo hizo el de cortesía, ya que "los tratadistas hispanos asumen la perspectiva de la civilidad bajo una etiqueta distinta", pero $\sin$ los mismos contenidos que la cortesía bajomedieval ${ }^{24}$. Se ha cuestionado el uso de los términos civilidad y civilización, para el ámbito hispánico por carecer de presencia en las fuentes documentales y principalmente porque invoca un "ideal cívico-político republicano del que en la España de la monarquía y el imperio colonial no existen referencias" y se optó, en distintos estudios españoles, por utilizar "cortesía moderna" en tanto código de conducta que persigue la depuración y corrección del comportamiento ${ }^{25}$.

Sin embargo, aquí se ha optado por mantener la palabra civilidad para el espacio rioplatense porque refiere a un fenómeno urbano centrado en el ascenso de la burguesía mercantil que buscaba diferenciarse tanto de la mirada europea sobre los americanos como de las distintas castas, por ejemplo en la admisión a la sociedad patriótica literaria comandada por Francisco Cabello y Mesa exigía el certificado de limpieza de sangre ${ }^{26}$. En los periódicos analizados entre 1801 y 1807, sólo aparece la palabra civilidad en la carta "Sobre las erradas prevenciones de los extranjeros en orden a nuestra situación económica", que bajo seudónimo publicó Manuel José de Lavardén en el Semanario de Vieytes, en referencia al México precolombino. Igualmente, se descartó el uso de "cortesía" para hacer referencia al modo de habitar la ciudad por la ausencia de corte en la sede virreinal rioplatense y porque el auge por la preocupación por las "buenas maneras", las "buenas costumbres" y la "urbanidad" tuvo como telón de fondo las reformas borbónicas, la ciudad, la cultura impresa, el comercio, la sociabilidad burguesa y la circulación de impresos y escritos extranjeros, por lo que se remarcaba el anclaje dinámico y moderno en lo "civil" antes que la tradicional y anquilosado de la "corte".

La preocupación académica por la tensión entre civilización y barbarie fue una constante en los primeros ensayos que intentaron indagar las raíces de la cultura en la América virreinal. La investigación sobre la civilidad se desarrolló en distintas sedes académicas, pero dejó de lado la conjunción entre la prensa, su circulación y apropiación así como la cuestión identitaria en las páginas periódicas. Las castas y los

\footnotetext{
J. Varela, op. cit., p. 85.

Ibidem.

24 F. Ampudia de Haro, Las bridas de la conducta: una aproximación al proceso civilizatorio español. CIS, 2007, p. 39.

$25 \quad$ Ibidem, p. 39.

26 M. Maggio Ramírez, "Civilidad a la mexicana. Lecturas de la Historia Antigua de México de Francisco Clavijero en la prensa virreinal de Buenos Aires (1801)". Nueva Revista de Filología Hispánica (NRFH), vol. 67, nº. 1, 2019, pp. 105-130. doi:10.24201/nrfh.v67i1.3466.
} 
campesinos encarnaron la barbarie para la prensa pero también los contrabandistas que corrompían la legalidad real. En la ciudad se definía la civilización en oposición a su contracara para configurar la identidad de la élite real.

Los distintos géneros discursivos que desde los periódicos abordaron cuáles eran los gestos, costumbres y prácticas apropiadas para la vida en la ciudad se sumaron a los textos que ya circulaban como los manuales de educación moral y cristiana, con un discurso instruccional y prescriptivo. No se estableció una norma sino que daban cuenta de su vigencia al criticar su incumplimiento, por ejemplo cuando las mujeres sabían los pasos de los bailes de moda pero que "ni el credo sepa[n] rezar"27. La vigencia de esa norma se encontraba anudada a la difusión que podía obtener por parte de la cultura impresa. La civilidad se transmite a través de ella para que en su aprendizaje se olvide, se "naturalice". La trasmisión cultural fue analizada como un proceso que olvida sus orígenes, y se destaca en prolongar "(con el riesgo, en ese mismo objetivo, de condensar sus formas de expresión: divisa, logo, apólogo, parábola, etcétera.)". Se centra "[...] en las cosas triviales más que en los «hombres ilustres» y los «grandes textos»" $" 28$. La mediación de la cultura escrita fue necesaria para trasmitir los conocimientos civilizados e ilustrados pero para que ese aprendizaje fuera eficaz se debía olvidar el impreso y su situación de lectura.

En la prensa, se esperaba que se imprimieran en las mentes de los niños textos de matriz instruccional en favor de la "felicidad del pueblo", por ejemplo aquellos en los que se enseñaban nuevas técnicas agrarias, con el objetivo de erradicar las enseñanzas que se habían transmitido de padres a hijos ${ }^{29}$. La interiorización de las normas sociales propias del proceso de civilización fue la principal apuesta de las élites letradas y la nueva burguesía mercantil, pero se encontró en contraposición con los viejos privilegios ligados a la limpieza de sangre, principalmente en el territorio americano.

En el interior propio del término civilización se escondía su amenaza, que es inseparable de su reverso, la "barbarie de nuestras civilizaciones" o una "falsa civilización", para el marqués de Mirabeau. El mundo "salvaje", sostuvo Jean Starobinski, "ya no se sitúa en el exterior, una lejana ribera o un profundo pasado; está disimulado en el propio lugar y no pide más que irrumpir desde el fondo tenebroso de la sociedad"30. La barbarie en el interior de la civilización.

La obra del abbé Raynal, que fue leída y criticada por los eruditos porteños, utilizó también la palabra civilización, según la investigación de Juan Goberna Falqué. Allí encontró que en la Histoire philosophique et politique des établissements et du commercer des Européens dans les deux Indes, de 1770, apareció la palabra pero en relación con el comercio: "[1]os pueblos que han poli a todos los otros han sido comerciantes". Para Raynal, poli significa exactamente civilizado, pues se pregunta: "[¿q]uién ha reunido, vestido, civilisé, a estos pueblos? Es el comercio"31. Starobinski recordó que entre las acepciones del verbo polir para 1680 se encontraba no sólo

27 "Satirilla festiva", Telégrafo Mercantil, Tomo 3, n 3, p. 39.

28 R. Debray, Transmitir, Buenos Aires, Manantial, 1997, p. 17.

29 "Lecciones elementales de agricultura por preguntas y respuestas, para el uso de los jóvenes de estas campañas", Semanario de Agricultura, Industria y Comercio, Tomo 1, n 44, pp. 345-350.

30 J. Starobinski, "La palabra civilización”, Prismas. Revista de Historia Intelectual, III (1999), pp. 9-36, aquí p. 25 .

31 J. R. Goberna Falque, Civilización: Historia de una idea, Santiago de Compostela, Universidade de Santiago de Compostela, 1999, p. 35. 
pulir o bruñir para sacar brillo, sino también, en sentido figurado, "civilizar, hacer más civil, galante y honrado" 32 .

Poli y policé, comentó Starobinksi, son palabras fonéticamente muy próximas. Los autores franceses jugaron con su similitud y las trataron de manera intercambiable, hasta el punto de que tuvieron su contraparte en español. Pablo Sánchez León sostuvo que el concepto de policía "nació alrededor del fallido intento de reunir las dos esferas de significado en un único campo semántico: ordenar la civilización en el doble sentido de imponerla por un acto de voluntad, y de darle un determinado or-den"33. El concepto de economía política, en boga durante el reformismo borbónico, fue útil para pensar el estancamiento español, tanto económico como moral, por la falta de comercio y trato con otras naciones. Durante el reinado de Felipe V (1715-1746), la idea de la decadencia del imperio español fue un leitmotiv. Para Jerónimo de Uztáriz, se podían contrarrestar los efectos del declive si se lograba "una "favorable disposición para el comercio»"34. También el conde de Campomanes, cuyas obras circularon en el ámbito rioplatense ${ }^{35}$, creyó que el comercio "afectaba a todas las relaciones humanas: desde el comercio, es decir, desde su falta o carencia, se podía dar incluso cuenta del deterioro del «celo de la patria» entre los vasallos de la Monarquía" "36. Los agentes considerados capaces de pulir a los individuos, además del trato en el comercio, son para el diccionario Trévoux: el tiempo, las letras, la corte, el arte y la conversación de las damas. Starobinski sostuvo que pueden ser civilizados los bárbaros, los provincianos y los jóvenes. En síntesis, toda naturaleza "feroz" y "grosera" antes de que el arte se haya ocupado de ella para perfeccionarla, es decir, modificarla en un proceso de dulcificación, ornamento y educación.

Durante el barroco, la cercanía semántica entre urbanidad, civilidad y comunicación fue anali-zada por Roger Chartier después de encontrar que en el Tesoro de la lengua castellana o española de 1611, Sebastián Covarrubias definió " "Comunicación, vale trato y amistad»", para más adelante indagar los sentidos del verbo «comunicar»: "En los comienzos del siglo XVII, comunicar supone no solamente o esencialmente transmitir una información, sino compartir, consultar, conversar, dar buen trato. La comunicación implica así honestidad, urbanidad y amistad"37. La investigación de Chartier continuó con el Diccionario de la Academia, que un siglo después definía comunicar, en una de sus acepciones, como "«tener comercio y trato familiar con alguno, así de palabra como por escrito»".

Era el comercio, la fuente civilizatoria de los pueblos americanos, en tanto instancia de comunicación entre América y Europa, según sostuvo el polígrafo limeño Hipólito Unanue en su "Discurso histórico sobre el nuevo camino del Callao de Lima", del Telégrafo Mercantil, cuando escribió que "[1] os caminos son entre los establecimientos públicos los que mejor caracterizan el grado de civilización de un

\footnotetext{
J. Starobinski, op. cit.

33 P. Sánchez León, “Ordenar la civilización: semántica del concepto de Policía en los orígenes de la Ilustración Espa-ñola”, Política y Sociedad, 42, 2005, pp. 139-156, aquí p. 141. [Disponible en http://revistas.ucm.es/ index.php/POSO/article/view/POSO0505330139A/22810]

$34 \quad$ Ibidem, p. 144.

35 J. Peire, op. cit., pp. 148-149

36 P. Sánchez León, op. cit., p. 145.

37 R. Chartier, "Introducción. Barroco y Comunicación", en C. Espejo, R. Chartier, La aparición del periodismo en Europa: comunicación y propaganda en el Barroco, Madrid, Marcial Pons, 2012, pp. 15-34, aquí p. 16.
} 
Estado [...]" ya que así se fomentaría el comercio ${ }^{38}$.

Durante el período virreinal, la identidad de la comunidad letrada porteña se demarcó en su civilidad, en las buenas costumbres y normas de urbanidad. Necesitaron difundirla entre quienes aún estaban estancados en los "tiempos idos" de la barbarie para lograr la felicidad del pueblo. En los primeros años de la prensa escrita rioplatense, la civilidad, en tanto "buenas costumbres", fue el signo identitario que la élite letrada se atribuía, en tanto oposición entre la "gente decente" y el "bajo pueblo" y las castas. La prensa tardocolonial tuvo la intensión de demostrar que la civilidad se había instalado en la ciudad como una forma de vida. La civilidad era la marca de un tiempo nuevo que se diferenciaba del pasado porque privilegiaba la "felicidad del pueblo", la cultura de la conversación, las tertulias, las "costumbres suaves" y por lo tanto el comercio, como sostuvo Montesquieu. La actividad mercantil necesitaba de acuerdos entre pares, por lo que en la prensa tardocolonial se destacó el que Buenos Aires se encontrara a la altura de las ciudades europeas. Se imaginaba que todos los frutos del país eran exportables, incluso aquellos que todavía no habían sido producidos. La agricultura y la industria eran los pasos anteriores al comercio que ponía a prueba la civilidad. Tanto Francisco Cabello y Mesa, editor del Telégrafo Mercantil, como Juan Hipólito Vieytes fueron sagaces propulsor del libre comercio como síntoma de las "buenas costumbres" de los porteños.

\section{Reformas borbónicas y comercio porteño}

Se fragmentó el virreinato del Perú en nuevos virreinatos como el de Nueva Granada en 1739 y el del Río de la Plata en 1776, así como también se crearon nuevas gobernaciones e intendencias. La plata potosina ya no iría camino a Perú para exportarse a España, sino que saldría por el puerto de Buenos Aires. La minería altoperuana financiaba la nueva estructura virreinal, por lo que el virrey de Buenos Aires prohibió la circulación de la plata potosina al Perú39. El 12 de octubre de 1778 se dictó el "Reglamento para el comercio libre", que dejaba de lado el monopolio para ampliar el comercio entre 13 puertos de España y 24 de América. El 4 de diciembre de 1778 se dictaron nuevas ordenanzas para los intendentes, instrumento básico de la reconquista burocrática y administrativa ${ }^{40}$. Un año después, se autorizó la libre trata de esclavos, lo que permitió el crecimiento de fortunas en el Río de la Plata que lucraron con su venta al interior del virreinato. Aumentó la inmigración española en América, no sólo de aquellos funcionarios dependientes de la nueva estructura burocrática sino también de quienes llegaban en búsqueda de un mejor destino. El comercio con España creció, pero la industria ibérica no respondió al mercado colonial, sino que fueron los comerciantes quienes tomaron el lugar de proveedores de productos manufacturados de procedencia extranjera. Lo esencial en la política regalista de los Borbones fue la eliminación de los privilegios disfrutados por las corporaciones, particularmente la Iglesia

${ }_{38}$ H. Unanue, "Discurso histórico sobre el nuevo camino del Callao de Lima", Telégrafo Mercantil, Tomo II, N. 28, 8/11/1801, p. 197.

39 R. Fradkin y J. C. Garavaglia, La Argentina colonial: El Río de la Plata entre los siglos XVI y XIX, Buenos Aires, Siglo Veintiuno Editores; Fundación OSDE, 2009, p. 186.

40 El reglamento se publicó en el Telégrafo Mercantil en 15 entregas desde el 1 de agosto y el 19 de septiembre de 1801. 
y la nobleza, y el "paradójico fortalecimiento de los poderes locales en América" ${ }^{41}$. La expulsión de los jesuitas del imperio ibérico en 1767 por acusaciones de fomentar el regicidio fue un golpe para la sociedad americana, donde las misiones habían desarrollado la economía, gracias a las prósperas actividades empresariales en sus estancias, y la cultura, a través de la fundación de colegios y la gestión de la educación superior. La obediencia de la Compañía de Jesús al Padre general, en tanto "monarca absoluto", fue interpretada por Pedro Rodríguez de Campomanes como que todo jesuita era un "enemigo de la Soberanía, [ya que] depende de un gobierno despótico residente en un país extranjero" ${ }^{42}$. A esos motivos se sumaron "la negativa de la compañía a abandonar la filosofía aristotélica, unida a una negativa igualmente firme a pagar la integridad del

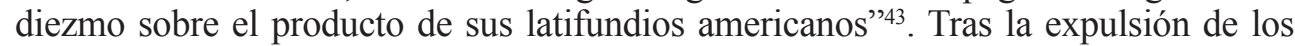
jesuitas, se prohibió la enseñanza del probabilismo, porque se creía que los religiosos fomentaban el regicidio a través de esa doctrina.

Los jesuitas necesitaron para sus tareas educativas de la escritura mecánica de la imprenta, que permitió reproducir las lecciones y libros de estudio y oración para los estudiantes de sus colegios. En la ciudad de Córdoba, en el Virreinato del Río de la Plata, contaban con una imprenta que dejaron en el colegio Monserrat hasta que fue reclamada por el virrey Juan José de Vértiz y Salcedo para instalarla en la ciudad sede del virreinato, en beneficio de la Casa de Niños Expósitos.

Las ciudades latinoamericanas se volcaron al comercio en el marco de una sociedad más abierta y aburguesada, donde cobraban vigor nuevas ideas sociales, culturales y políticas. Las reformas acentuaron el autoritarismo y los tradicionales grupos de presión, nobleza y clero, fueron sometidos a una política regalista para limitar su poder. Respecto de la educación, las reformas no sostuvieron la alfabetización de grandes masas, sino que se consideró importante seleccionar a los mejores e inculcarles las nuevas ideas ilustradas, cifradas en la Enciclopedia de Diderot y D' Alambert ${ }^{44}$. El ideal ilustrado se focalizó en el saber práctico y utilitario que permitía mejorar la calidad de vida, a diferencia del saber escolástico que no se ocupaba de resolver temas mundanos. Las claves económicas del período se centraron en la agricultura y el comercio, al punto de que se dedicaron periódicos a estos temas, como el Semanario de Agricultura y Artes dirigido a los párrocos, editado en Madrid pero leído con furor en América. Los reformadores borbónicos no sólo se ocuparon de mejorar los ingresos de las arcas virreinales, sino que también mejoraron la iluminación urbana y la atención sanitaria con la creación del Protomedicato ${ }^{45}$.

Desde 1763, con la paz de París, las potencias coloniales hicieron lo posible para fortalecer sus enclaves y "remediar la laxitud administrativa que la guerra había puesto al descubierto", por lo que se aumentó el control sobre las colonias para que fuesen más lucrativas y que no compitieran económicamente con las metrópolis ${ }^{46}$. Las reformas borbónicas apuntaron al fortalecimiento de la actividad mercantil, la

41 C. García Ayluardo, op. cit., p. 12.

42 D. Brading, op. cit., p. 36.

43 D. Brading, "Comentario", en C. García Ayluardo (coord.), Las Reformas Borbónicas, 17501808, México, Fondo de Cultura Económica, 2010, pp. 337342, aquí p. 341.

44 J. L. Romero, Latinoamérica: las ciudades y las ideas, Buenos Aires, Siglo Veintiuno Editores, 2001 , p. 151.

45 S. Socolow, 'Introducción', en L. S. Hoberman y S. Socolow, Ciudades y sociedad en Latinoamérica colonial, México, Fondo de Cultura Económica, 1993, pp. 7-28, aquí p. 11.

46 P. K. Liss, Los imperios transatlánticos: las redes del comercio y de las revoluciones de Independencia, México, Fondo de Cultura Económica, 1995, p. 43. 
creación de adunas y el aumento de puertos habilitados para contar con mayores ingresos impositivos. El comercio fue la palabra de orden para quienes querían salir de un estancamiento cada vez más anacrónico en la ciudad donde la libertad mercantil se asociaba con el progreso, en el que la naciente burguesía criolla creyó de manera inusual ${ }^{47}$. La burguesía en ascenso se sentía comprometida "con su ciudad y su región, y por eso asumieron con firmeza el papel de élite: no mucho después pensaron en la independencia política, y la alcanzaron a través de revoluciones urbanas que ellos encabezaron"48.

Frente al crecimiento comercial de la ciudad, la corona necesitó recabar información, por lo que se desarrollaron censos que indicaron el crecimiento poblacional a partir de 1744: se pasó de "algo más de 26.000 a casi 43.000 personas. Este aumento de cerca del 63\% indica que Buenos Aires era una de las ciudades de más rápido crecimiento en Hispanoamérica durante la última fase del período colonial" ${ }^{\text {"99. El }}$ crecimiento poblacional se debió a la inmigración europea y española, al aumento del comercio esclavo, a los movimientos migratorios internos dentro del virreinato y al crecimiento vegetativo. El crecimiento de la población negra frente a los "españoles" fue síntoma de riqueza, pero también estableció pautas y reglas sociales por parte de la burguesía para habitar la ciudad y evitar el cruce con castas consideradas inferiores, por ejemplo en el Colegio Carolino. Los grupos inmigrantes más destacados desde finales del siglo XVIII fueron varones españoles y nativos del interior del virreinato. Los primeros estuvieron presentes en las ocupaciones urbanas más prestigiosas y mejor remuneradas en la jerarquía ocupacional de la ciudad, pues controlaban no sólo la burocracia, la iglesia y las profesiones liberales sino también el comercio y las artesanías. Entre 1776 y 1810, sólo 19 comerciantes mayoristas de una muestra de 140 de ellos residentes en Buenos Aires habían nacido en América y, de ellos, 3 habían venido del interior ${ }^{50}$. Para 1778 hubo una mayor densidad de población en el centro de la ciudad debido al desplazamiento de las actividades rurales a las urbanas, por lo que las casas tuvieron habitaciones que el comerciante mayorista alquilaría tanto a artesanos con su familia cuanto a comerciantes minoristas. Los edificios representaban un microcosmos de la vida social y económica de la ciudad, al albergar bajo un mismo techo a familias del sector comercial, burocrático $\mathrm{y} \operatorname{artesanal}^{51}$.

Los comerciantes mayoristas constituyeron el grupo más poderoso socialmente, ya que "Buenos Aires no tenía títulos nobiliarios, ni grupos poderosos de hacendados, una iglesia pobre y pocos burócratas del gobierno (por lo menos hasta la creación del Virreinato y establecimiento de la Audiencia) [... ${ }^{352}$. Si bien sólo el $15 \%$ de los comerciantes eran criollos, se encontraban mejor educados que sus pares españoles porque provenían de un estrato socioeconómico más alto. Manuel Belgrano recordó que la característica principal del comerciante español en tiempos del Consulado era "que no sabían más que su comercio monopolista, a saber: comprar

\footnotetext{
J. L. Romero, op. cit., p. 119.

48 Ibidem, p. 120.

49 L. Johnson, y S. Socolow, "Población y espacio en Buenos Aires del siglo XVIII", Desarrollo Económico 20, 1980, pp. 329-349, aquí p. 221.

50 Ibidem, p. 337.

51 Ibidem.

52 S. Socolow, "La burguesía comerciante de Buenos Aires en el siglo XVIII", Desarrollo Económico 18, 1978, pp. 205-216, aquí p. 206.
} 
por cuatro para vender por ocho [...] con su espíritu de monopolio para no perder el camino que tenían para enriquecerse" ${ }^{53}$. El progreso económico estaba anudado al crecimiento comercial pero también de la civilidad. Las costumbres suaves y el diálogo que fueron utilizados en la prensa tardocolonial como términos causales para lograr la felicidad pública.

\section{Corte, comercio y civilidad}

Entre las instituciones que se crearon con las reformas borbónicas, el consulado de comercio de Buenos Aires se ocupó, bajo la dirección de Manuel Belgrano, del fomento económico de la región. Belgrano poco antes de graduarse y volver a Buenos Aires en 1794 con el cargo de Secretario Perpetuo del Consulado de Comercio, escribió desde España a su padre Domingo. Buscaba consejo de su progenitor, comerciante italiano radicado en Buenos Aires, para enfrentar en la Corte a "estos hombres que llamamos Agentes [que] no son otra cosa que unos hombres que nada hacen" 54 . Preocupado, le comentó a su padre sobre "[...] estos casos [que] están sucediendo todos los días con los pobres Americanos que no conociendo la baraúnda de la Corte se entregan y se fían de los hombres sin conocer la malicia que puede caber en sus corazones; si esto nos sucede a los que estamos aquí, qué será a los que están miles de leguas distantes" 55 .

Años después, en su Teatro crítico universal, el benedictino Benito Feijoo (1778: 237) reforzó la crítica de la urbanidad fingida. Allí, Feijoo aseveraba que "[...] los hipócritas de la urbanidad son innumerables [... y] cuyo ser está todo en gestos, y labios, sin que el corazón tenga parte alguna en esas demostraciones; antes bien ordinariamente está obstruido de todos los afectos opuestos" ${ }^{56}$. Mediante una cita de los Pensamientos escogidos del Abad Boileau sobre la corte parisina, el benedictino insistía en que el espíritu cortesano no se caracterizaba por la sinceridad sino por los malos oficios, los enredos y los engaños. Feijoo, cuya obra fue central entre los eruditos dieciochescos, tuvo al igual que los americanos que dezconocían la corte las mismas críticas a su puesta en escena.

La falta de conocimiento de los códigos sociales propios de la Corte española marcó para el americano una distancia simbólica entre quienes compartían ese mundo y quienes no. Al reinar la "confusión y ruido grande, estrépito, bulla y notable desorden y mezcla de cosas", definición de la Real Academia Española (RAE) en su Diccionario de Autoridades de 1726 para la palabra "barahunda", no se encontraban las reglas para actuar frente a la puesta en escena de la cortesanía que impedía, según Belgrano, conocer la malicia que hay en los corazones. El diccionario de la RAE aclaraba la etimología de "barahunda" al recordar su origen arábigo en barahan, que significa argüir. Es significativo notar que argüir, es decir, argumentar frente una opinión, terminó significando ruido y bulla. Territorio del artificio y la ficción, la

53 M. Belgrano, “Autobiografía del General Don Manuel Belgrano”, en Autobiografias. Biblioteca de Mayo, Buenos Aires, Imprenta del Congreso de la Nación, 1960,Tomo 2, Vol. 1, pp. 955-100, aquí p. 957.

54 M. Belgrano, Epistolario belgraniano, Buenos Aires, Taurus, 2001, p. 55.

55 Ibidem.

56 B. J. Feijoo, "Discurso 10. Verdadera, y Falsa Urbanidad", en Teatro Crítico Universal, Madrid, Real Compañía de Impresores y Libreros, 1778, Tomo 7, p. 237. Disponible en http://www.filosofia.org/bjf/bjft710.htm 
Corte era donde se establecían lazos comerciales. Se trataba de un espacio en el que quien no compartía los códigos se sentía engañado frente a las máscaras que ocultaban la malicia. Belgrano reclamaba una autenticidad y naturalidad sin trampas, sin mediaciones, de los agentes comerciales, por lo que ponía en relieve "una lucha por la hegemonía social y cultural, en la que las elites ilustradas aspiraban a legitimarse esgrimiendo un ideal moral, pedagógico y estético de austeridad y utilidad" ${ }^{57}$. Las buenas costumbres, las buenas maneras, la urbanidad, la civilidad y la cortesanía eran sinónimos que guardaban una codificación del hecho social en diferentes escalas, que iban desde la configuración de las formas para dirigirse en una tertulia a una mujer casada hasta la puesta en escena del boato real en distintos acontecimientos. La civilidad era entendida como un conjunto de códigos a través de los cuales era "posible aproximarse a las visiones del mundo y a las reglas que rigen el funcionamiento social" 58 . La experiencia de Belgrano antes de llegar a Buenos Aires lo puso sobre aviso de la tensión entre los pares dicotómicos: ser y parecer, naturaleza y cultura, individuo y sociedad, privado y público, autenticidad y artificio, entre otros. El comercio era la danza en el baile de máscaras, tanto la codificación de la legislación como la sociabilidad ligada al baile en ese encuentro dialógico del comprador y el vendedor fueron una señal de progreso y adelantamiento de las costumbres, según los teóricos de la historia natural y la economía política.

En los primeros números de su Semanario de Agricultura, Industria y Comercio, Vieytes indagó qué se entendía por cada uno de los términos del título del impreso. El orden en nada aleatorio de los temas que trató el periódico retomaba la mirada de la Ilustración escocesa y francesa, que anudaba el progreso material y la civilidad de los pueblos. Este cruce ya se encontraba en los primeros números del Telégrafo Mercantil en el artículo "Idea general del comercio de las Provincias del Río de la Plata" 59 , que concluyó con una "Oda al comercio" ${ }^{60}$. El fomento del comercio se relacionó con el "divertimento de los sentidos" que evitaba que los hombres se despedazasen "los unos a los otros a manera de brutos salvajes". La oda anónima que siguió al texto retomó la misma idea del comercio como etapa necesaria para la civilización. Los hombres pasaron de imitar a las fieras, "en sus brutalidades; / desnudo, libre y solo, / a sus necesidades, / buscando algún abrigo / entre los matorrales" a transformarse en seres civilizados gracias a que el comercio los "redimió de salvajes / los trajo a poblaciones / los redujo a ciudades, /reinos, cortes e imperios". En una nota al pie a la "Oda...", el editor escribió que no le extrañaría al autor lo que le fue suprimido del texto. En esa primera señal de censura en la prensa porteña quedaba de manifiesto que el comercio era un tema que podía generar conflictos. Anudado en la prensa el comercio junto al progreso, económico y moral, se enfrentaban las lecturas de los filósofos de gabinete europeos que imaginaron el territorio americano como un espacio sin matices, gobernado por la desidia, el ocio y la holgazanería que implicaba la barbarie. Los artículos sobre el comercio, además de la información sobre entradas y salidas de barcos o de las mercaderías que llegaban a los puertos, intentaron demostrar que Buenos Aires y

\footnotetext{
M. Bolufer Peruga, "El arte de las costumbres. Una mirada sobre el debate de la civilidad en la España del siglo XVIII”, Res Publica 22, 2009, pp. 195-224, aquí p. 197.

$58 \quad$ Ibidem, p. 195.

59 Telégrafo Mercantil, Tomo 1, N³, 8/4/1801, pp. 17-19.

60 Ibidem, pp. 19-22.
} 
Montevideo era ciudades civilizadas.

Los comerciantes fueron presentados en la prensa como "agentes civilizadores" al encarnar las buenas costumbres ligadas al trabajo, el diálogo, la utilidad y la legalidad, en oposición a los contrabandistas. La oposición entre la nobleza improductiva y el comerciante se aprecia en la "Oda al comercio":

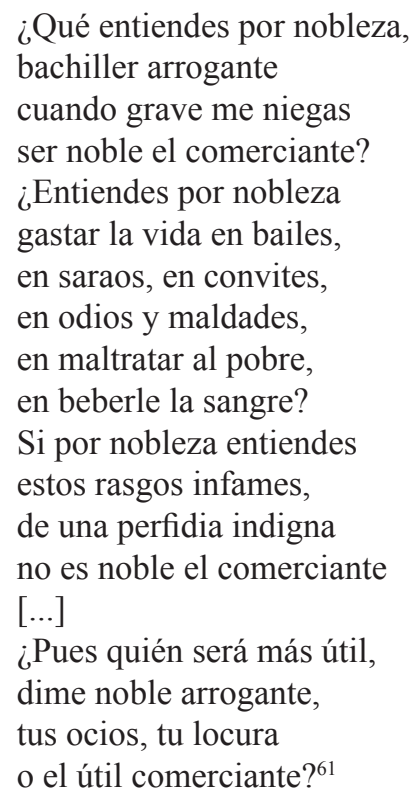

Se representó a la nobleza como ociosa, arrogante, centrada en la sociabilidad de bailes y saraos, sin el ejercicio de ninguna actividad laboral, como un resabio de la legislación sobre artes y oficios. La contraparte era el comerciante: la utilidad de su trabajo y sus costumbres suaves estaban ligadas a la moderación en la vida social. En la "Oda..." se prefiguraron los tópicos que meses más adelante se tratarían en las "Lecciones de un camilucho a su hijo", por ejemplo la crítica al contrabando. La cuarta fábula de Domingo de Azcuénaga en el Telégrafo se tituló "El comerciante y la cotorra" 2 . El comercio era una tarea arriesgada, ya que "sin culpa ni causa" se podía caer desgracia. La sociabilidad que se gozaba por la buena fortuna se desvanecía, se perdía al íntimo amigo hasta que la suerte cambiara para tenerlo "al lado sin falta;/ pero mientras dure/ el nublado en casa,/ no pienses, que vuelva/ a verte la cara" ${ }^{3}$. Los frutos del comercio eran la contraseña para escalar y deambular en los salones de la burguesía mercantil a falta de nobleza, pero esa vida entre lujos era efímera, según la lección moral de Azcuénaga.

Para Vieytes, "[1]a experiencia de todos los siglos nos demuestra que el grado de civilización, cultura y opulencia a que puede llegar una nación es solamente debida a la más o menos acogida y libertar que hay dado a su comercio" ${ }^{64}$. El número 4 del

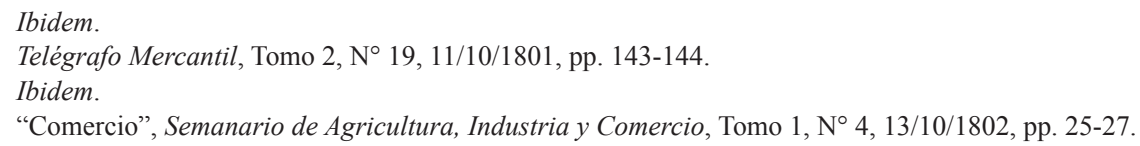


Semanario apuntaba a mudar las costumbres del labrador para que "[1]a tierra sin cultura, los campos despoblados, los ganados manejados sin economía, y sin provecho, todo esto nos anuncia la infancia de nuestra industria, y lo mucho que tenemos que correr para alcanzar a la felicidad que ha desterrado de nuestras provincias la inacción" ${ }^{5}$. El comercio erradicaría la pereza y la holgazanería, que eran los vicios que se les criticaban a los americanos en la literatura dieciochesca.

\section{Civilidad y caminos}

Hipólito Unanue, médico limeño y colaborador del Mercurio Peruano, publicó en 1801 un Discurso histórico sobre el nuevo camino del callao de Lima y, el 8 de noviembre del mismo año, se lo reprodujo en el Telégrafo Mercantil ${ }^{66}$. Cabello conoció a Unanue cuando lanzó en Perú su emprendimiento Diario de Lima, por lo que compartieron las penurias de las labores periodísticas. Médico con una profunda erudición, heredero de las preocupaciones barrocas del literato Pedro Peralta y Barnuevo, revisitó el universo metafórico organicista para comprender la importancia de los caminos en la civilización. En tanto catedrático de prima de anatomía, utilizó su formación para darle sentido al mundo que trataba de abordar. Los caminos eran "arterias para el cuerpo natural, forman en el político los canales por donde giran los espíritus que lo animan y vivifican" ${ }^{67}$. Los caminos, como las arterías, servían para la "comunicación que tienen entre sí diversas soledades". Así como concebía a la ciudad como espacio preponderante de la civilidad, consideraba que la comunicación y el comercio se configuraba en oposición al "salvaje aislado en medio de los bosques [que] apenas puede formar hordas miserables en cuya holgazanería y estupidez se sepultan su alma y corazón". Acorde al nuevo paradigma médico que indagaba la transmisión de la electricidad a través de las fibras nerviosas, Unanue esgrimió sin dudar que "los pueblos en comercio de frotan y electrizan recíprocamente" para colocarlos "en el alto destino que los separa de la naturaleza irracional". El comercio, gracias a los caminos, distingue al "hombre social" del "hombre salvaje" que vive encerrado, sin contactos con otros individuos que le permitan conformar villas y ciudades.

El médico limeño rastreó la importancia de los caminos, desde Asia, "cuna del género humano y de las primeras monarquías", hasta el siglo XVIII, e hizo especial hincapié en los caminos que "el Nuevo Mundo ofreció a los ojos de sus conquistadores, en testimonio de su civilización calzadas suntuosas en México; grandes caminos en el Perú", que de la plaza del Cuzco se dirigían hacia los cuatro puntos cardinales para terminar en los confines del imperio Inca. La identidad americana, narrada desde el hemisferio sur, se reforzó en una nota al pie cuando la descripción de las vías

65 Ibidem.

${ }^{66}$ El 13 de junio de 1802 se publicaron en el Telégrafo unas líneas que Unanue fechó el 23 de marzo, donde el médi-co limeño escribió: "He visto y leído con placer sumo, muchos rasgos del erudito Telégrafo que Ud. compone pu-blicados en el Correo Mercantil de Madrid, y espero en breve también tener el gusto de verlos traducidos al francés e inglés, como lo tengo de poseer, y en este, varios discursos del Mercurio Peruano [...] celo patriótico debe la América meridional los periódicos que en estos tiempos le van dando estimación, que borrará entre los sabios de Europa la mal consabida idea de la barbarie de sus habitantes".

${ }^{67}$ H. Unanue, "Discurso histórico sobre el nuevo camino del Callao de Lima", Telégrafo Mercantil, Tomo II, N. $28,8 / 11 / 1801$. 
y senderos americanos se contrapuso con "Mr. Pauw y algunos otros [, que] negaron la existencia de caminos". Los caminos, a pesar de las ventajas para el comercio y la civilidad de los pueblos, fueron "olvidados en el Perú, y aún en toda la América española después de su conquista; [...] que forman la cadena que enlaza las naciones del globo a fin de que se vayan reuniendo en un pueblo humano y comerciante"

La realización del camino que llegaba de Lima hasta la Bahía del Callao permitió no sólo que el comerciante calculara "tranquilamente las ganancias que han de reportar[le] sus viajes", sino también que el filósofo descubriera el paisaje de "un mar pacífico que lleva en sus espaldas una república comerciante"69.

Entre otros textos contemporáneos en los que se articulaba la importancia de los caminos para el fomento del comercio, y por ende de las producciones agrícolas y manufactureras, se podría volver a la carta de Mariano Frequeriar, publicada en el Semanario de Vieytes. El lector recomendó al editor que se abocase a narrar "[e]1 reciente descubrimiento del nuevo camino para Chile dará a Vm. materia para hacernos interesante su periódico por algún tiempo. La descripción de los países por donde ha transitado el descubridor", así como las producciones de aquel suelo y "el carácter de sus naturales, su forma de gobierno, usos, ritos, y costumbres, su plan de vida, la extensión de las comunicaciones comerciantes que mantienen con otras naciones $[\ldots]^{\prime \prime 70}$. Vieytes, en una nota al pie a la carta, esperaba que durante el próximo viaje que se emprendiera por ese camino se llevase un diario, "aunque semejantes documentos no son del todo suficientes cuando no son formados por una mano inteligente", pero prometió tratar el tema en el número siguiente ${ }^{71}$. Una semana más tarde, recurrió a sus lecturas sobre Adam Smith para justificar la necesidad de abrir caminos internos que fomentaran el comercio doméstico, para luego pensar en el externo, tal como ha hecho el gobierno inglés, que usó diestramente "de aquellos dos grandes resortes que mueven de continuo al hombre, que son el interés, y el amor propio [...]"72. Camino y comercio era una relación establecida que los literatos del siglo XVIII interpretaron como un cruce que fomentaba la civilidad de los pueblos.

\section{El contrabando en la prensa}

A partir de las mercaderías decomisadas en los puertos de Buenos Aires y de Montevideo, se publicó entre el 27 de mayo y el 3 de junio de 1801 en el Telégrafo el artículo "Rasgo político moral sobre contrabandos" ". El corresponsal anónimo recriminó a los contrabandistas que, por querer avanzar en el ramo mercantil, violaban la ley y, en consecuencia, ofendían a "Dios, al soberano y a su patria. Es mal cristiano, mal vasallo y mal ciudadano" 74 . Para argumentar su postura, el autor recordó que Santo Tomás de Aquino sostuvo que "la observancia de las leyes civiles es una obligación que transciende al fuero de la conciencia, y que su infracción es un atentado indirecto

\footnotetext{
Ibidem.

69 Ibidem.

70 "Carta de D. Mariano Frequeriar proponiendo los objetos que debe abrazar este Periódico", Semanario de Agricultura, Industria y Comercio, Tomo 1, No 40, 22/6/1803, pp. 316-319.

Ibidem.

Ibidem.

Telégrafo Mercantil, Tomo 1, № 17, 27/5/1801 - 3/6/1801.

Ibidem.
} 
contra la misma ley eterna de Dios". Infringir la legislación contra el contrabando implicaba cometer una "infracción a pecado mortal". El pago de impuestos no sólo se presentaba como una manera para sostener la vida en sociedad, porque los reyes por medio de las alcabalas "conservan y defienden el estado consultando la paz y tranquilidad universal", sino también como una virtud religiosa, ya que en el Nuevo Testamento se lee: "Dad a Dios lo que es de Dios, y a César lo que es del César". Por más que el contrabando fuera una práctica tradicional en el Río de la Plata, se advertía que "la repetición de actos pecaminosos, no puede fundar licitud contra la ley divina que sostiene la honestidad y justicia de las alcabalas". El contrabandista simplemente no era un buen ciudadano. Se lo comparaba con el jugador, que siempre se encuentra dispuesto a perder su patrimonio. El contrabando se representaba como un medio rápido para estar a la moda, porque se "gana una, dos y tres veces seguidas, se llena de hinchazón", galantea, derrocha, compra "hebillas de oro, relojes de repetición, mesas y taburetes a la inglesa", tapiza su casa y aposento, regala a su mujer sortijas y batas, alquila coches y "costea espléndidos banquetes en Barracas, San Isidro, y las Conchas". En la ficción ejemplar que se utilizó para compararlo con el contrabandista, el jugador, una vez que perdió su dinero en las apuestas, "fuma, bebe, suspira, medita, finge alegre el semblante, y vase en fin a acostar. Golpea reciamente la puerta. Entra maldiciendo. Riñe y golpea a la mujer y criados, sin que hayan tenido la culpa. Acuestase aunque no duerme" y sale de su casa en búsqueda de una nueva partida. Tentar la suerte en el juego era la misma práctica que llevaba adelante el contrabandista, quien apostaba sus ingresos y se encontraba en los límites de la civilidad, porque golpea a su mujer y criados aunque finja su semblante. El comercio implicaba acatar las legislaciones que enmarcaban la actividad, por lo que se establecía un marco civilizatorio que el contrabandista rompía, aunque simulase en público con los signos de un buen pasar, obtenidos en desmedro de la felicidad pública.

\section{Cierre}

el contrabandista se olvida del tierno interés que le debe merecer la causa pública, y falta a las primeras obligaciones de buen ciudadano.

Telégrafo Mercantil, Tomo 1, p. 141

La historia de los conceptos en el Río de la Plata ahondó en la íntima relación entre las categorías ciudadano/vecino. El vecino, en tanto hombre libre y urbano, era quien "podía elegir a los funcionarios y que, a la vez podía ser elegido: españoles o hijos de españoles con limpieza de sangre, raigambre y prestigio"75. El ciudadano como vecino de la ciudad habría de contar con un capital no sólo material sino simbólico que era propio del saber vivir en la urbe. Frente al caso particular rioplatense en el que "los vecinos de prestigio ocuparon el lugar de la nobleza faltante" fue una estancia previa a la ciudadanía. El comercio, en tanto actividad principal de la élite porteña, habría de contar con sus propios códigos de civilidad para ser apreciada

\footnotetext{
75 O. C. Casanello, "Ciudadano/Vecino", en N. Goldman (comp.), Lenguaje y revolución. Conceptos políticos clave en el Río de la Plata, 1780-1850, Buenos Aires, Prometeo, pp. 19-34, aquí p. 19.

76 Ibidem, p. 20.
} 
la actividad frente a los vecinos. La crítica al contrabando funcionaba como vara del deber ser en el ámbito simbólico. La élite letrada encontró en la civilidad un signo que les permitió diferenciarse de la otredad en sus múltiples encarnaciones y para validarse frente a la mirada europea. La prensa fue el terreno donde floreció la civilidad ligada a la vecindad y como antesala a la ciudadanía. Luego del fracaso del primer periódico impreso en Buenos Aires, dirigido por Francisco Antonio Cabello y Mesa, Telégrafo Mercantil, Rural, PolíticoEconómico e Historiográfico del Río de la Plata, y tras el cierre por la segunda invasión inglesa del Semanario de Agricultura, Industria y Comercio de Juan Hipólito Vieytes, la ciudad se quedó sin papeles impresos que dieran a publicidad "las luces de Europa", salvo por un par hojas volantes y la reimpresión de la Gaceta de Gobierno de Sevilla. Manuel Belgrano, que había colaborado con los periódicos anteriores, decidió entonces solicitar la autorización virreinal para publicar el Correo de Comercio. La autorización del virrey Baltasar Hidalgo de Cisneros le permitió, a principios de 1810, publicar un papel periódico que tuviera como fin lograr "[...] la propagación de las luces, y los conocimientos útiles [...]". En el mes de febrero de 1810 hizo circular el prospecto de su Correo de Comercio, impreso "con Superior Permiso" en "Buenos Ayres en la Real Imprenta de Niños Expósitos".

Belgrano, sin pudor, escribió que "[... Buenos Aires es] la gran Capital de la América Meridional, digna hoy de todas las atenciones del mundo civilizado"77. El mundo civilizado es el europeo, desde donde emanan las luces de la Ilustración, que oficia como meta de llegada, como norma y espejo donde mirarse. Buenos Aires, es digna "hoy" - escribió Belgrano- a unos meses de la Revolución de Mayo. El uso del deíctico "hoy" no puede dejar de leerse en su oposición al "ayer", en el que por ende la ciudad no era digna de las "atenciones" de Europa, más aún si recordamos las descripciones de Alonso de Solórzano y Velasco, quien describió las miserias de la ciudad antes de que la actividad comercial inundara sus calles. De acuerdo con el diccionario de la RAE de 1803, la "atención" reclamada por Belgrano se definía como acción de atender, proveniente del latín attentǐo. Un segundo significado rescataba el uso ligado a la cortesanía, urbanidad, en tanto señal de respeto u obsequio, comitas, observantia, urbanitas. Para ser digna de respeto, la ciudad tuvo que pensarse a sí misma, al menos en la escritura de Belgrano, como un territorio civilizado donde reinaba la cortesía, entendida en el mismo diccionario como "la acción o demostración corporal con que se manifiesta la atención y el buen modo que se deben unos a otros", por lo que indica una situación de igualdad, de pares que conocen un código común de cómo habitar y vivir en el mundo social. Entre la situación de los americanos que no conocían las normas sociales de la Corte en España y la ciudad porteña en los confines australes del imperio español que se encontraba ya a la par de las europeas no pasaron más de veinte años. En tanto proceso, no podrían datarse sus comienzos, múltiples y azarosos, pero sí es posible dar cuenta de las tensiones y las críticas de las costumbres que se hicieron presentes en la superficie de los periódicos impresos en tanto fosilización discursiva de un magma imaginario, propio de las élites letradas, que centró en el comercio el emblema de la civilidad moral.

77 Prospecto del periódico que se intenta publicar con el título de Correo de Comercio", Correo de Comercio, Tomo 1, Buenos Aires, Academia Nacional de la Historia de la República Argentina, 1970. [Disponible en https://babel.hathitrust.org ] 